\title{
Realitas Pemikiran Islam: Moderat-Puritan
}

\author{
Djami’atul Islamiyah \\ Dosen IAIN Salatiga \\ d2017islamiyah@gmail.com
}

\begin{abstract}
The distinction of Khaled Abou El Fadl, the moderate-puritan is actually only one of the distinction models of Islam. Other distinctions include "liberal-conservative" from Ann Elizabeth or the "Islamic and Islamic fundamentalism" from Bassam Tibi. The emergence of these distinctions is related to differences in understanding the interaction with non-Muslims and the concept of salvation in the context of religious plurality. It is hard to imagine that they both read and interpret the same source (the Qur'an) but in terms of the output interpretation, these two groups are very diametrical and incompatible. This raises a question of what their premises and logic are in order to make a difference in describing the will of God. If the difference is only on the level of discourse, it might not be too worrisome. The problem is the difference in the interpretation implied on the rise of violence in the name of religion. So aside from causing negative image on Islam as a violent and intolerant religion, as well as the word "Islam" has generated negative sentiments in various countries, starting from a nonchalant attitude that has a lot of suspicion to fear and hatred. El Fadl realizes that the Islamic world can not be reduced in these two categories only. The reality of modern Islam is much more complex and there is another orientation of thought. But at least this distinction can illustrate the existence of schism in Islamic thought between moderate Islam and puritan Islam lately.
\end{abstract}

Keywords: moderate, puritan, salvation-concept

\begin{abstract}
Abstrak
Distingsi Khaled Abou El Fadl, moderat puritan sesungguhnya hanya merupakan satu di antara model-model distingsi tentang Islam. Distingsi lain misalnya "liberal-konservatif" dari Ann Elizabeth atau distingsi "Islam dan fundamentalisme Islam" dari Bassam Tibi. Munculnya distingsi ini terkait dengan adanya perbedaan dalam memahami interaksi dengan non muslim dan konsep keselamatan dalam konteks pluralitas agama. Sulit dibayangkan bahwa mereka sama-sama membaca dan menafsirkan sumber yang sama (al-Qur'an) namun dalam hal out put penafsiran dua kelompok ini amat diametral dan tidak sejalan. Hal ini mengundang tanda tanya bagaimana sesungguhnya premis dan logika mereka sehingga dapat menghasilkan perbedaan dalam menjabarkan
\end{abstract}


Millatī, Journal of Islamic Studies and Humanities, Vol. 2, No. 2, Des. 2017: 145-168

kehendak Tuhan. Jika perbedaan itu hanya ada pada tataran wacana mungkin tidak terlalu mencemaskan. Masalahnya adalah perbedaan penafsiran tersebut berimplikasi pada maraknya kekerasan atas nama agama. Sehingga di samping menimbulkan image negatif pada Islam sebagai agama yang keras dan tidak toleran, juga kosa kata Islam telah menimbulkan sentimen negatif di berbagai negara. Mulai dari sikap acuh tak acuh yang syarat kecurigaan hingga ketakutan dan kebencian yang amat sangat. El Fadl menyadari bahwa dunia Islam tidak bisa direduksi dalam dua kategori ini saja. Realitas Islam masa kini jauh lebih kompleks dan terdapat orientasi pemikiran yang lain. Namun paling tidak distingsi ini dapat menggambarkan adanya skisma dalam pemikiran Islam antara Islam moderat dan Islam puritan belakangan ini.

Kata kunci: moderat, puritan, konsep keselamatan

\section{Pendahuluan}

Khaled Abou El-Fadl dikenal sebagai seorang pakar dalam bidang hukum Islam, saat ini dia menjadi profesor hukum University of California Los Angeles (UCLA). Sebelumnya, dia pernah mengajar di sejumlah universitas ternama di Amerika, seperti: Universitas Yale, Universitas Princeton, dan Universitas Texas. Dia juga pernah menjabat sebagai Direktur Human Right Watch dan anggota Komisi Kebebasan Beragama, AS. Di samping itu, dia seringkali diundang dan mengisi seminar, simposium, lokakarya, termasuk menyempatkan diri untuk mengisi acara talkshow, baik di televisi maupun radio, seperti: CNN, NBC, NPR, dan VOA. Sebagai pakar hukum Islam, dia banyak berbicara tentang imigrasi, Hak Asasi Manusia (HAM), serta hukum keamanan nasional dan internasional, juga banyak memberikan komentar tentang isu-isu tentang otoritas, terorisme, dan toleransi. Karya dan pandangan-pandangan el-Fadl telah ikut mewarnai blantika pemikiran Islam kontemporer, bahkan tidak berlebihan jika dia yang dilahirkan di Kuwait 1963 itu banyak disebut-sebut sebagai pemikir paling produktif dan populer setelah Fazlur Rahman.

Karya-karya tulisan El-Fadl antara lain: Speaking in God's Name: Islamic Authority, and Women (One world, 2001), Rebellion and Violence in Islamic Law (Cambridge University Press, 2001), And God Knows The Soldiers: The Authoritative and Authoritarian ini Islamic Discourses (University Press of America, 2001), The Authoritative and The Authoritarian in Islamic Discourses: A Contemporary Case Study (al-Saadawi Publishers, 2002, The Place of Tolerance in Islam (Beacon Press, 2002), Islam and The Challenge of Democracy (Princeton University Press, 2004). 
Selain karya-karya tersebut, buku The Great Theft: Wresting Islam from The Extremists adalah karya penting El-Fadl juga. Buku tersebut kemudian diterjemahkan oleh Helmi Mustafa dengan judul "Selamatkan Islam dari Muslim Puritan tahun 2006”. Sekalipun dalam judul bukunya tertulis kata ekstrimis, namun dalam distingsi yang dibuat el-Fadl menggunakan kata puritan dan moderat. Istilah puritan menurut el-Fadl sudah dideskripsikan oleh banyak penulis dengan istilah: fundamentalis, militan, ekstrimis, radikal, fanatik, dan jahidis. Namun dia lebih suka memakai istilah puritan karena ciri menonjol kelompok ini dalam hal keyakinannya menganut paham absolutisme dan tidak kenal kompromi. Dalam banyak hal, orientasi kelompok ini cenderung menjadi puris, dalam arti ia tidak toleran terhadap berbagai sudut pandang yang berkompetisi dan memandang realitas sebagai suatu bentuk kontaminasi atas kebenaran sejati. ${ }^{1}$

Ada semacam kegelisahan akademik tersendiri, saat dia menulis buku tersebut, yaitu maraknya pemberitaan lewat media massa tentang muslim ekstremisme, daftar aksi-aksi kekerasan yang secara moral memalukan, seperti sandera yang terjadi di Iran dan Libanon, ancaman pembunuhan dan penganiayaan terhadap para penulis dan pemikir, ${ }^{2}$ sikap tidak toleran yang berlebihan terhadap perempuan dan kaum minoritas agama yang dilakukan oleh Taliban di Afganistan, bom bunuh diri di berbagai belahan dunia, dan lain-lain. Akibatnya tidak berlebihan jika dikatakan bahwa dalam benak banyak orang di dunia, Islam telah sangat terasosiasikan dengan apa yang bisa digambarkan sebagai hal yang negatif-intoleran, penindasan, kekerasan dan penganiayaan, terlepas apakah orang percaya bahwa pandangan mengenai Islam dan kaum muslimin ini cukup berdasar atau tidak, sudah menjadi fakta tak terbantahkan bahwa di banyak belahan dunia, kosa kata Islam itu sendiri membangkitkan sentimen negatif, mulai dari sikap acuh tak acuh yang syarat kecurigaan hingga ketakutan atau kebencian yang amat sangat. ${ }^{3}$ Pendapat El-Fadl tersebut misalnya dapat kita lihat pada ungkapan ini "in the popular mind, notably in the west, the concept of fumdamentalism has negative connotation and is almost exclusively applied to Islam. ${ }^{4}$

${ }^{1}$ Khaled Abou El-Fadl, Selamatkan Islam dari Muslim Puritan, Helmi Mustofa (Penerjemah), (Jakarta: Serambi Ilmu Semesta, 2006), h. 29.

${ }^{2}$ Misalnya kasus Nasr Hamid Abu-Zaid, yang diklaim sebagai orang yang murtad oleh kelompok fundamentalis Islam Mesir, karena pendapatnya "bahwa umat Islam perlu belajar memisahkan antara agama itu sendiri dan pemahaman manusia terhadap agama”, selengkapnya baca: Ancaman Fundamentalisme, Bassam Tibi, Imron Rosyid, dkk (Penerjemah), (Yogya: Tiara Wacana, 2000), h. X-XI.

3 Khaled Abou El-Fadl, Selamatkan Islam dari Muslim Puritan, h. 14.

${ }^{4}$ Gerrieter Haar and James J. Bussuti (ed), The Freedom to Do God's Will, (London: 
Millatī, Journal of Islamic Studies and Humanities, Vol. 2, No. 2, Des. 2017: 145-168

Permasalahannya adalah apakah aksi-aksi mereka memiliki akar rujukan ynag cukup kuat pada teologi dan hukum Islam? Dengan kata lain apakah agama mengajarkan sikap prejudice dan kekerasan? Bagaimana seorang muslim mendamaikan iman yang mengakar kuat di hati dengan persepsi publik yang dominan di dunia non muslim? $?^{5}$ Dalam hal ini El-Fadl memberi jawaban "orangorang Islam harus melakukan kritik diri dan perubahan yang bercorak introspektif terhadap tradisi dan keyakinan mereka sendiri. ${ }^{6}$ Maka membangun kembali (rekonstruksi) Islam sebagai kekuatan moral humanis di dunia adalah agenda penting saat ini. Namun yang menjadi fokus dalam buku ini sebagaimana dia katakan, bukanlah merancang satu program rekonstruksi yang bersifat sistematis, melainkan mendeskripsikan realitas pemikiran Islam yang ada belakangan ini. ${ }^{7}$ Dalam konteks inilah tulisan ini dimaksudkan untuk mendeskripsikan El-Fadl yang merupakan abstraksi dari realitas dinamika pemikiran umat Islam dalam memahami agama mereka yang dia tuangkan dalam distingsi Moderat-Puritan yang akan dijelaskan sebagai berikut.

\section{Moderat dan Puritan: Distingsi El-Fadl}

Ada beberapa tujuan dengan deskripsi El-Fadl tentang distingsi Moderat-Puritan. ${ }^{8}$ Pertama, untuk menekankan perbedaan mendasar antara dua ujung spektrum yang sangat berperan dalam menentukan masa depan Islam. Kedua, model distingsi yang dipaparkan El-Fadl ini diharapkan dapat memberikan pemahaman bagi kaum non muslim mengenai bentuk keyakinan dan pendirian yang diambil oleh

Routledge, 2003) h. 3. Terkait dengan hal ini, El-Fadl sendiri pernah disebut sebagai seorang islamis yang sembunyi-sembunyi, atau sebagai seorang ekstrimis yang menyokong agenda militan, baca El-Fadl, hlm. 11: istilah islamis, misalnya digunakan oleh ED Husaim dalam bukunya The Islamist, 2006, England, Penguin Books. Buku ini menceritakan tentang pengalaman pribadinya ketika dia bergabung dengan Islam Radikal di Inggris, setelah dia mengetahui semua sisi-sisi kelemahannya, dia memutuskan keluar dari kelompok ini.

Islamis adalah kaum muslim yang yakin bahwa teologi dan hukum Islam seharusnya berposisi sebagai suatu kerangka acuan otoritatif dalam setiap kondisi sosial dan politik, ElFadl, h. 32.

5 Khaled Abou El-Fadl, Selamatkan Islam dari Muslim Puritan, h. 15.

${ }^{6}$ Ibid., h. 15 dan 24.

7 Ibid., h. 15.

${ }^{8}$ Distingsi lain misalnya, Liberal-Conservative dari Ann Elizabeth Meyer dalam bukunya: "Islam and Human Rights: Tradition and Polities, (London: West View Press, 1995), h. 2, sementara Bassam Tibi membuat distingsi agak berbeda, yaitu Islam dan Fundamentalisme Islam, Imran Rasyidi dkk (penerjemah), (Yogya: Tiara Wacana, 2000), h. 25. 
umat Islam. Ketiga, membantu umat Islam untuk mengevaluasi hubungan mereka dalam spektrum ide dan keyakinan melalui penjelasan-penjelasan yang ada. ${ }^{9}$

Meskipun harus juga diakui bahwa dunia modern Islam tidak bisa diringkas ke dalam dua kategori itu saja. Realitas Islam masa kini jauh lebih kompleks dan terdapat orientasi pemikiran yang lain. ${ }^{10}$ Namun paling tidak distingsi ini dapat menggambarkan adanya skisma dalam pemikiran Islam antara Islam moderat $^{11}$ dan Islam puritan yang ada belakangan ini. Istilah moderat sering digambarkan orang sebagai modernis, progresif, dan reformis. Namun bagi ElFadl tak satu pun dari istilah-istilah itu yang bisa menggantikan istilah moderat. Di samping itu, hadits-hadits Nabi meriwayatkan bahwa manakala dihadapkan pada dua pilihan ekstrem, Nabi selalu memilih jalan tengah (khoirul umuri ausathuha). Munculnya distingsi tersebut terutama terkait dengan pandangan mereka dalam memahami interaksi dengan non muslim dari konsep keselamatan atau yang terkait dengan pluralitas agama. Terkadang sulit dibayangkan bahwa orang-orang puritan dan moderat membaca dan menafsirkan sumber agama yang sama. Hal ini dikarenakan out put penafsiran dua kelompok ini amat diametral dan tidak sejalan. Kondisi semacam ini menimbulkan pertanyaan seperti apa sebenarnya metode penafsiran mereka sehingga dapat melahirkan perbedaan dalam menjabarkan kehendak Tuhan. Makna yang terkandung dalam teks-teks agama sangat dipengaruhi oleh kecenderungan serta komitmen moral dan etis para pembaca teks tersebut. Namun (El-Fadl menambahkan) makna tersbeut juga dipengaruhi oleh perangkat teknis yang dipakai orang dalam memahami teks. Akan tetapi dalam pembahasan di bukunya ini El-Fadl tidak memfokuskan diri pada perangkat heuristik orang-orang moderat dan puritan serta metode yang mereka gunakan. Dia lebih fokus pada kesimpulan teologis dan yurisprudensial

9 Ibid., h. 26.

${ }^{10}$ Komarudin Hidayat menyebut respon keberagaman seseorang terhadap agama memiliki orientasi dengan kecenderungan berbeda-beda, setidak-tidaknya terdapat 3 tipe keberagaman, kecenderungan mistikai (solitary), profetik-idiological (solidarity), dan humanis-fungsional, untuk lebih jelasnya baca "Atas Nama Agama”, Andito (ed), (Bandung: Pustaka Hidayah, 1998), h. 43.

${ }^{11}$ Istilah moderat sering juga disebut dengan modernis, progresif, reformis, ibid., h. 27, pada h. 12. Dia juga menyebut istilah moderat dengan liberal. Namun dia lebih memilih istilah moderat karena al-Qur'an memerintahkan umat Islam untuk menjadi orang yang moderat. Di samping itu, hadits-hadits Nabi meriwayatkan bahwa manakala dihadapkan pada dua pilihan ekstrem, Nabi selalu memilih jalan tengah (Khoirul Umuri Ausathuha). Di sinilah istilah moderat menemukan akarnya di dalam tradisi Islam dan tradisi ini mentransmisikan karakter normatif yang diharapkan dimiliki mayoritas muslim (h. 27). 
Millatī, Journal of Islamic Studies and Humanities, Vol. 2, No. 2, Des. 2017: 145-168

yang dicapai orang moderat dan puritan. ${ }^{12}$

Menurut El-Fadl konsep tentang keselamatan bagi orang-orang puritan sangat jelas dan sederhana. Hanya muslim yang akan punya peluang keselamatan di hari akhir, sementara orang-orang non muslim tidak berhak atas keselamatan. Ayat al-Qur'an yang menjadi rujukan terkait hal ini adalah surat Ali Imron ayat 85 dan ayat 19 sebagai berikut:

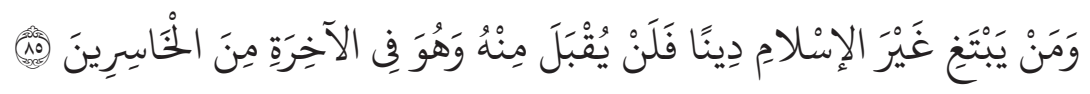

Artinya: "Barang siapa mencari agama selain agama Islam, maka sekali-kali tidaklah akan diterima (agama itu) daripadanya, dan dia di akhirat termasuk orang-orang yang rugi"(85).

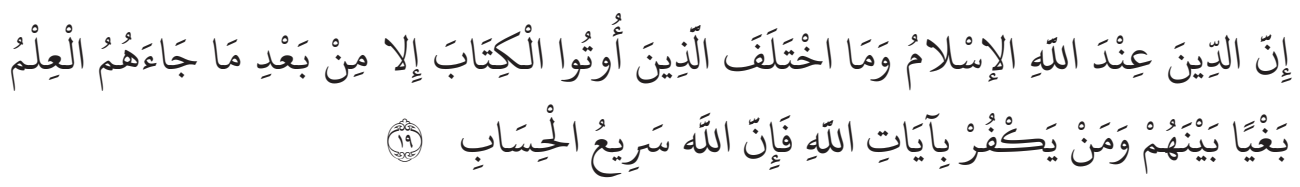

Artinya: "Sesungguhnya agama (yang diridai) di sisi Allah hanyalah Islam. Tiada berselisih orang-orang yang telah diberi Al Kitab kecuali sesudah datang pengetahuan kepada mereka, karena kedengkian (yang ada) di antara mereka. Barang siapa yang kafir terhadap ayat-ayat Allah maka sesungguhnya Allah sangat cepat hisab-Nya"(19).

Kata Islam dalam ayat tersebut, secara ketat diartikan oleh kelompok puritan (literalist: Tariq Ramadan) sebagai agama yang dibawa oleh Nabi Muhammad Saw. Lebih lanjut puritan juga mengklaim umat Islam yang tidak memeluk keyakinan dan praktik yang benar, sebagaimana didefinisikan oleh orang-orang puritan, tidak akan mendapatkan keselamatan juga. Perbedaan mendasar antara muslim yang berdosa atau melakukan bid'ah dan kaum non muslim menurut kalangan puritan, adalah tingkatan neraka yang bakal diperuntukkan bagi mereka. Kaum non muslim akan menempati level neraka lebih rendah ketimbang muslim yang berdosa atau melakukan bid'ah. ${ }^{13}$

Klaim puritan bahwa hanya orang-orang muslim yang akan memperoleh keselamatan didasari atas premis mereka yang merasa lebih unggul dan superior terhadap non muslim. Mereka yakin bahwa hanya mereka yang memiliki kebenaran (truth claim) eksklusif dan bahwa semua yang lain celaka. ${ }^{14}$

\footnotetext{
${ }^{12}$ Ibid., h. 244.

${ }^{13}$ Ibid., h. 245.

${ }^{14}$ Ibid., h. 258
} 
Menurut El-Fadl, logika semacam ini dapat menjurus pada keyakinan yang arogan bahwa kelompok lain tidak mungkin memiliki nilai yang setara. Tidak perlu dipertanyakan lagi bahwa dalam kasus kelompok-kelompok muslim puritan, ide-ide mereka melalui keselamatan dan kutukan memberi andil pada kesadaran bahwa mereka lebih unggul dan superior yang telah digunakan untuk menjustifikasi perilaku tak manusiawi dan bahkan kejam. ${ }^{15}$

Adalah hal yang wajar, banyak agama menyatakan bahwa orang-orang yang tidak mau mempercayai ajaran mereka akan dihukum dengan berbagai cara. Tetapi yang berbeda adalah sikap penolakan orang-orang puritan berlaku hingga dalam kehidupan di muka bumi ini. ${ }^{16} \mathrm{Hal}$ ini sekaligus juga menjelaskan pola relasi terhadap kelompok non muslim dan juga penolakan ide pluralitas

Pandangan puritan tentang the only salvation claim (meminjam istilah Arkoun pada gilirannya akan melahirkan sikap eksklusifme yaitu "a believer in a particular religion to take is that the truth lies within his or her own religion and that any religion holding opposing views is therefore false". William L. Rowe, Philosophy of Religion, ..., (California: Wardsworth Publishing Company) h. 173. Eksklusifisme adalah pandangan bahwa kebenaran absolut hanya dimiliki agama tertentu secara eksklusif tidak memberikan alternatif lain, tidak memberikan konsensi sedikit pun dan tidak mengenal kompromi, baca "Islam Liberal, Pluralisme Agama, dan Diabolisme Intelek". Adian Husaini, (Surabaya: Risalah Gusti, 2005) h. 233. Pengakuan bahwa agama sendiri merupakan satu-satunya agama yang benar, sementara agama lain pasti salah, tidak didukung bukti yang kuat dan sikap yang jujur dan netral, keputusan sepihak lebih menentukan dalam hal ini dan ikatan emosional merupakan penguatnya kalau bukan dasarnya yang paling bawah. Baca "pluralisme dalam semangat kesatuan transendental, Machasin. TH. Sumartama dalam buku Pluralisme Konflik dan Pendidikan Agama Islam di Indonesia, (Yogya: Pustaka Pelajar, 2001), h. 8. Ayat-ayat al-Qur'an yang sering digunakan sebagai membatasi penyelamatan hanya pada Islam, misalnya surat Al Imron ayat 85 dan ayat 19. Menurut Amin Abdullah "sangat sulit untuk mempertahankan paradigma tunggal dalam diskursus apapun, semuanya serba beraneka ragam, semua perlu dipahami dan didekati dalam multi dimensional approach" baca Falsafah Kalam. M. Amin Abdullah, (Yogya: Pustaka Pelajar, 1995) h. 104.

${ }^{15}$ Khaled Abou El-Fadl, Selamatkan Islam dari Muslim Puritan, h. 258.

Sikap eksklusifme pada gilirannya akan memunculkan sikap ganda defensif dan osfensif sekaligus. Dengan sikap yang pertama sesorang akan mempertahankan mati-matian terhadap intervensi kebenaran yang datang dari agama lain dan dengan sikap yang kedua seseorang akan membentangkan jalan keselamatan kepada para pemeluk agama lain. Baca Islam dan Hegemoni Sosial, 2003, Khaeroni (ed.) Jakarta.

${ }^{16}$ Ibid., h. 245.

Menurut Amin Abdullah, membicarakan pluralisme barat "to put a new wine in the old bottle" dalam arti isu-isu pluralisme adalah setua usia manusia yang selamanya akan ada. Isu ini menjadi hangat kembali seiring dengan lajunya pemikiran post modernisme yang ditandai oleh 3 struktur pemikiran yaitu dekonstruksi, relasivisme, dan pluralisme. Baca Filsafat Kalam, Amin Abdullah, 1995, h. 99. Dalam konteks Indonesia, isu pluralisme menjadi akut terkait fatwa MUI 2005, tentang larangan pluralisme di Indonesia, baca Dian Husaini, op.cit., hlm. v. 
Millatī, Journal of Islamic Studies and Humanities, Vol. 2, No. 2, Des. 2017: 145-168

agama yang tidak saja memiliki referensi historis tapi juga normatif. Sebagaimana disebutkan dalam surat al Maidah ayat 48:

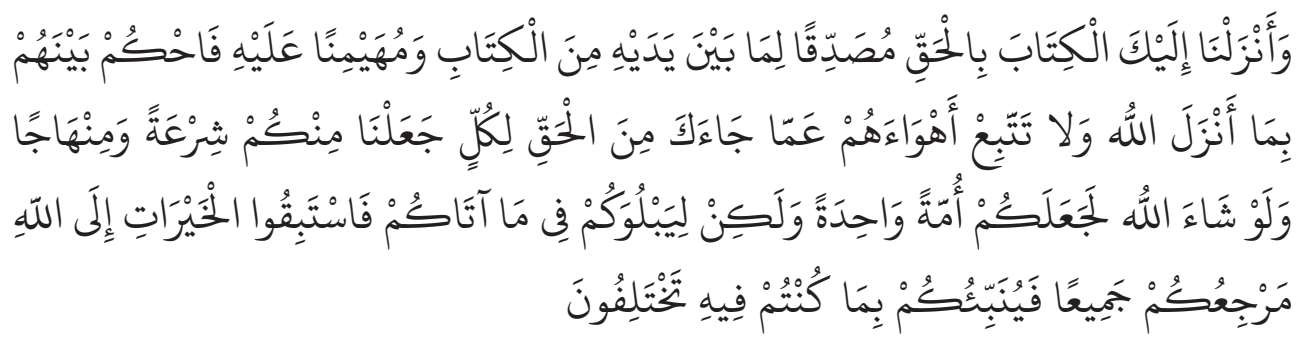

Artinya: "Dan Kami telah turunkan kepadamu Al Qurian dengan membawa kebenaran, membenarkan apa yang sebelumnya, yaitu kitab-kitab (yang diturunkan sebelumnya) dan batu ujian terhadap kitab-kitab yang lain itu; maka putuskanlah perkara mereka menurut apa yang Allah turunkan dan janganlah kamu mengikuti hawa nafsu mereka dengan meninggalkan kebenaran yang telah datang kepadamu. Untuk tiap-tiap umat di antara kamu, Kami berikan aturan dan jalan yang terang. Sekiranya Allah menghendaki, niscaya kamu dijadikan-Nya satu umat (saja), tetapi Allah hendak menguji kamu terhadap pemberian-Nya kepadamu, maka berlomba-lombalah berbuat kebajikan. Hanya kepada Allah-lah kembali kamu semuanya, lalu diberitahukan-Nya kepadamu apa yang telah kamu perselisihkan itu".

Orang-orang puritan menerima tanpa syarat atau tanpa revisi pada praktik tradisionil yang dinamakan status dzimmah bagi kaum non muslim yang hidup di wilayah muslim. ${ }^{17}$ Menurut sistem status dzimmah, kaum non muslim harus membayar pajak sebagai bayaran atas perlindungan dari muslim dan hak untuk tinggal di wilayah muslim. Melalui sistem ini kaum non muslim dibebaskan dari pengabdian militer, namun mereka tidak diberi ruang untuk menempati posisi tinggi yang berkaitan dengan kepentingan-kepentingan level tinggi Negara. Pandangan mereka didasarkan pada sebuah premis bahwa Islam harus menguasai dan mendominasi. Konskuensinya kaum non muslim yang hidup di wilayah muslim harus dibuat merasa inferior agar mereka segera tidak tahan dengan status mereka. Kondisi ini akan menjadi titik masuk bagi mereka untuk melihat kebenaran dan beralih ke Islam, sehingga mereka dapat melepaskan status rendah mereka. ${ }^{18}$

${ }^{17}$ Tentang status dzimmah dan kewajiban-kewajiban mereka, baca: El-Fadl, loc.cit., salah satu ambiguitas pemikiran puritan adalah apa yang harus dilakukan terhadap orang-orang kafir yang bukan Nasrani atau Yahudi.

${ }^{18}$ Ibid., h. 245 dan 248. 
Pandangan orang-orang puritan ini memiliki dua kutub, di satu sisi ada Islam yang mempresentasikan kebaikan mutlak dan di sisi lain ada non muslim yang mempresentasikan kejahatan. Bersandar pada tulisan-tulisan beberapa ahli hukum klasik, puritan mengajukan teologi yang dikenal dengan sebutan "alwala' wa-al bara' (doktrin loyalitas dan pemisahan). ${ }^{19}$ Fakta bahwa non muslim bukanlah muslim dilihat sebagai kesalahan moral. Jika umat Islam peduli dengan mereka, ini berarti pertanda bahwa umat Islam lebih mendahulukan emosi ketimbang komitmen agama mereka, sebuah tanda yang jelas akan lemahnya iman.

Sementara kalangan puritan meyakini bahwa kaum non muslim adalah situasi temporer dan umat Islam (sebagai satu-satunya umat yang berhak akan keselamatan) harus berusaha keras untuk memperbaikinya dan bahwa dunia pada akhirnya harus diislamkan. Orang-orang moderat justru menolak logika ini sebagai sesuatu yang bertentangan dengan kehendak Tuhan. Kalangan moderat beranggapan bahwa al-Qur'an tidak hanya menerima, melainkan bahkan mengharapkan realitas perbedaan dan keragaman dalam masyarakat manusia. ${ }^{20}$ Dalam hal itu dia merujuk surat al Hujurat ayat 13:

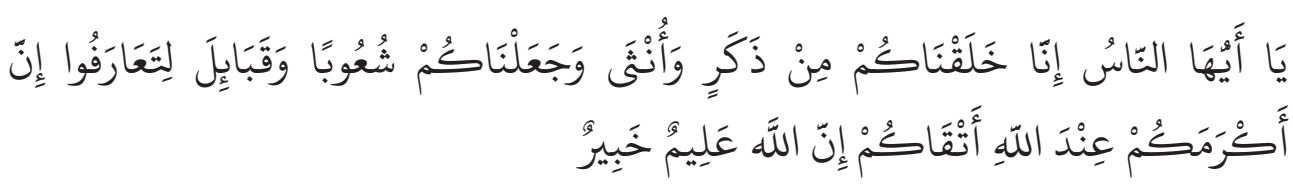

Artinya: "Hai manusia, sesungguhnya Kami menciptakan kamu dari seorang laki-laki dan seorang perempuan dan menjadikan kamu berbangsa-bangsa dan bersuku-suku supaya kamu saling kenal mengenal. Sesungguhnya orang yang paling mulia di antara kamu di sisi Allah ialah orang yang paling bertakwa di antara kamu. Sesungguhnya Allah Maha Mengetahui lagi Maha Mengenal".

\section{${ }^{19}$ Ibid., h. 248.}

Orang-orang moderat menolak sistem dzimmah. Menurut mereka di era modern ini sistem tersebut akan menghalangi kerja sama kebaikan dan keadilan di dunia. Selengkapnya baca, h. 257. Dalam konteks ini, An-Naim mengatakan "semua tradisi budaya keagamaan, menganut prinsip aturan emas (golden rule) yakni sebuah prinsip yang mengatakan bahwa siapapun memperlakukan orang lain seperti dia mengharapkan orang lain memperlakukan dirinya". Baca, Toward in Islamic Reformation ...., Abdullah Ahmed An-Naim, (New York: Syracuse University Press, 1990), h. 162-163.

${ }^{20}$ Ibid., h. 249.

Baca juga, "Religious Plurality: promoting a peaceful and harmonious society within diversity", tulisan Alwi Shihab dalam buku Quo Vadi Islamic Studies in Indonesia, Komarudin Amin, dkk (ed), (Jakarta: Dikti Islam, Depag RI, 2006), h. 57. 
Millatī, Journal of Islamic Studies and Humanities, Vol. 2, No. 2, Des. 2017: 145-168

Juga surat Hud ayat 118-119:

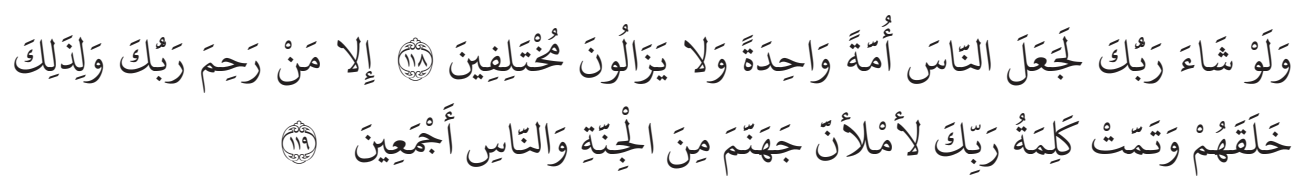

Artinya: "Jika Tuhanmu menghendaki, tentu Dia menjadikan manusia umat yang satu, tetapi mereka senantiasa berselisih pendapat (18). Kecuali orang-orang yang diberi rahmat oleh Tuhanmu. Dan untuk itulah Allah menciptakan mereka. Kalimat Tuhanmu (keputusan-Nya) telah ditetapkan: sesungguhnya Aku akan memenuhi Neraka Jahanam dengan jin dan manusia (yang durhaka) semuanya" (19).

Dalam memahami konsep keselamatan ini pemikiran moderat menggunakan beberapa prinsip, Pertama adalah bahwa Tuhan dan hanya Tuhan semata yang merupakan Raja hari akhir dan karenanya kebijakan Tuhan sangat tidak terbatas sebagaimana firman Allah dalam surat Ali Imron ayat 128-129:

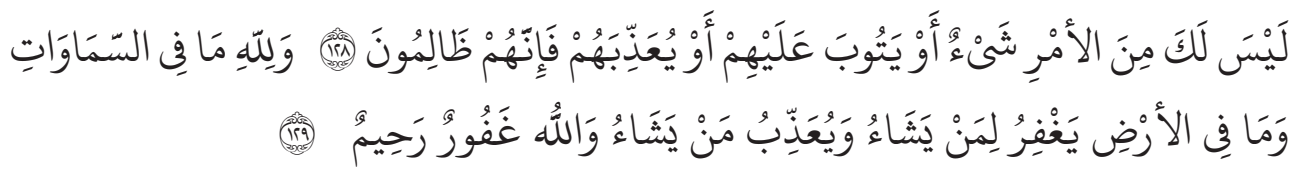

Artinya: "Tak ada sedikit pun campur tanganmu dalam urusan mereka itu atau Allah menerima tobat mereka, atau mengazab mereka, karena sesungguhnya mereka itu orang-orang yang lalim (128). Kepunyaan Allah apa yang ada di langit dan yang ada di bumi. Dia memberi ampun kepada siapa yang Dia kehendaki; Dia menyiksa siapa yang Dia kehendaki; dan Allah Maha Pengampun lagi Maha Penyayang (129)".

Kedua, Tuhan membuat komitmen kepada manusia berkenaan dengan akibat-akibat keyakinan dan tindakan mereka. Sebagaimana disebutkan dalam surat Al-Hajj ayat 67-69:

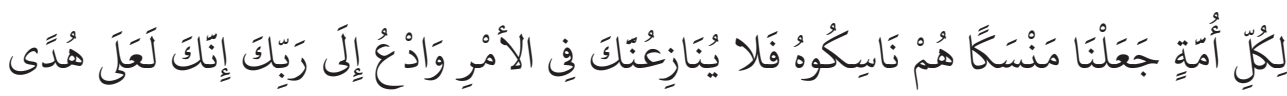

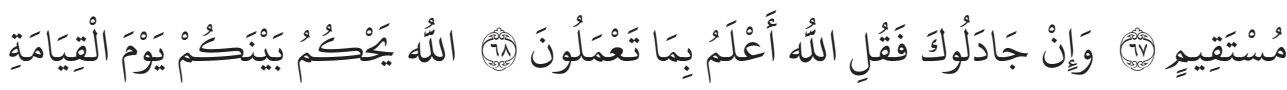

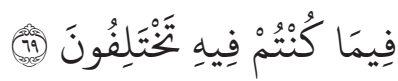

Artinya: "Bagi tiap-tiap umat telah Kami tetapkan syariat tertentu yang mereka lakukan, maka janganlah sekali-kali mereka membantah kamu dalam urusan (syariat) ini dan serulah kepada (agama) Tuhanmu. Sesungguhnya kamu benar-benar berada pada jalan yang lurus (67). Dan jika mereka membantah kamu, maka katakanlah: «Allah 
lebih mengetahui tentang apa yang kamu kerjakan» (68). Allah akan mengadili di antara kamu pada hari kiamat tentang apa yang kamu dahulu selalu berselisih padanya (69)".

Ketiga, al-Qur'an tidak sepenuhnya mengesampingkan kemungkinan bahwa bisa jadi ada jalan lain menuju keselamatan. Salah satu komponen dari isu ini berkaitan dengan siapa yang bisa dan berhak untuk mendapatkan kemurahan Tuhan. Tentang hal ini al-Qur'an lagi-lagi menegaskan kebijaksanaan Tuhan yang tak terbatas untuk melimpahkan kemurahan dan rahmat-Nya kepada siapa saja yang dikehendakiNya. Sesungguhnya al-Qur'an mengungkapkan kemarahan pada mereka yang mencoba membatasi rahmat Tuhan berdasarkan kemauan dan hasrat mereka sendiri. Hal ini dikarenakan bahwa Nabi dikirim ke dunia ini sebagai rahmat bagi manusia ${ }^{21}$ (Surat al-Anbiya' ayat 107).

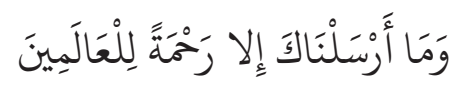

Artinya: "Dan tiadalah Kami mengutus kamu, melainkan untuk (menjadi) rahmat bagi semesta alam”.

Di samping itu, hanya Tuhan yang memutuskan siapa yang bakal menerima rahmat-Nya, baik di dunia maupun di akhirat dan dipandang sebagai tindak pelanggaran besar bagi umat manusia untuk berupaya mengira-ira siapa yang layak atas rahmat Tuhan dan siapa yang tidak. ${ }^{22}$ Surat al Baqarah ayat 105:

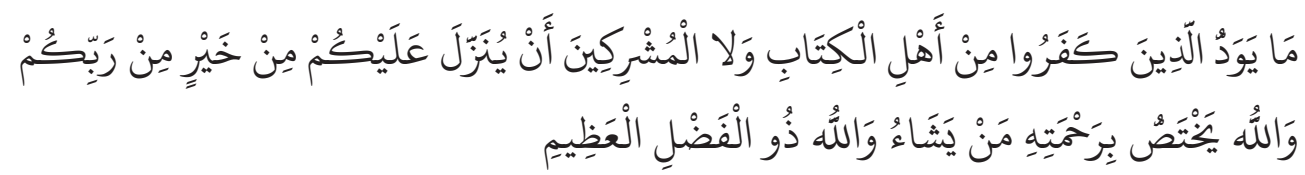

Artinya: "Orang-orang kafir dari Ahli Kitab dan orang-orang musyrik tiada menginginkan diturunkannya sesuatu kebaikan kepadamu dari Tuhanmu. Dan Allah menentukan siapa yang dikehendaki-Nya (untuk diberi) rahmat-Nya (kenabian); dan Allah mempunyai karunia yang besar".

Dalam ayat lain surat al Hajj ayat 34:

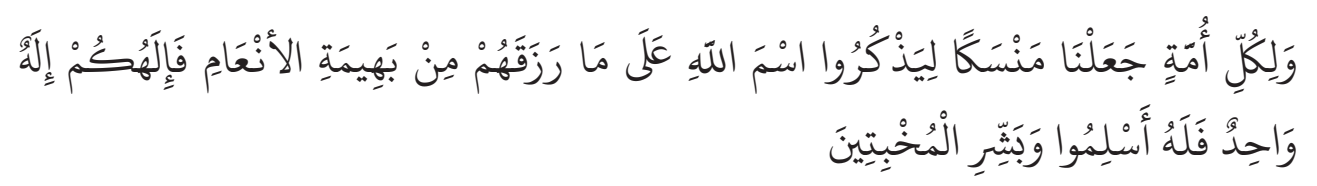

${ }^{21}$ Ibid., h. 258-259.

${ }^{22}$ Ibid. 
Millatī, Journal of Islamic Studies and Humanities, Vol. 2, No. 2, Des. 2017: 145-168

Artinya: "Dan bagi tiap-tiap umat telah Kami syariatkan penyembelihan (kurban), supaya mereka menyebut nama Allah terhadap binatang ternak yang telah direzekikan Allah kepada mereka, maka Tuhanmu ialah Tuhan Yang Maha Esa, karena itu berserah dirilah kamu kepada-Nya. Dan berilah kabar gembira kepada orang-orang yang tunduk patuh (kepada Allah)”.

Ayat ini mengisyaratkan bahwa berbeda apapun jalan-jalan itu, jalan-jalan itu masih diarahkan menuju Tuhan. ${ }^{23}$ Menariknya al-Qur'an mengakui bahwa mereka yang menyembah Tuhan pantas menerima berita gembira dan bahwa persoalan utamanya adalah keberserahan diri kepada Tuhan. ${ }^{24} \mathrm{Hal}$ ini berarti bahwa dalam konstruk pemikiran orang-orang moderat, kata-kata 'Islam' dalam al-Qur'an lebih dimaknai kepada makna generiknya ketimbang pengertian teknikal sebagai derivasi dari kata Islam. Yang dimaksud dengan makna generik di sini adalah sebelum Islam menjadi "proper name” agama bagi Nabi Muhammad.

Sebagaimana ditulis Nurcholis Majid "semua agama itu pada mulanya menganut prinsip yang sama, yaitu keharusan untuk berserah diri kepada Yang Maha Esa, maka agama-agama itu baik karena dinamika internalnya sendiri atau

${ }^{23}$ Bila kita merujuk pada pendekatan filsafat semua agama pada dasarnya menuju pada "the real". "The real" ini merupakan sebuah konsep universal. Dalam konteks Barat "the real" ini kemudian dibahasakan dengan "the ultimate reality", atau dalam konteks Arab disebut "al Haqq" dan dalam budaya sanskrit diucapkan dengan "Sat", sekalipun "the real" ini diterjemahkan berbeda sesuai dengan kultur historis masing-masing, namun secara substansi yang dituju oleh agama adalah satu "the real", the final object of religious concern as "the real". Mircea Eliade (ed) The Encyclopedia of Religion, Volume II, (New York: Simon dan Schuster Macmillan), h. 332, dalam praxis kehidupan proses memaknai "the real" tersebut membuat klaim tentang kebenaran menjadi beragam pula. Islam mengklaim bahwa hanya agama Islamlah yang paling benar, demikian juga pada Kristen dan agama-agama lain. Dilihat dari alur pikir ini maka sebetulnya yang berbeda-beda itu adalah pemaknaan atau interpretasi tentang "the real" atau the ultimate reality dan bukan terletak pada "the ultimate reality" itu sendiri. Bermuara dari perbedaan interpretasi inilah konflik-konflik tentang kebenaran biasanya terjadi bukan saja konflik antar agama namun juga intern agama.

Filsafat sebagai pendekatan keilmuan setidaknya ditandai oleh 3 ciri. Pertama, kajian, telaah, dan penelitian fundamental terhadap objek persoalan yang sedang dikaji. Kedua, pengenalan, pendalaman persoalan dan isu-isu fundamental dapat membentuk cara berpikir yanng bersifat kritis. Ketiga, kajian dan pendekatan filsafat yang bersifat demikian diharapkan akan dapat membetuk mentalitas, cara berpikir, dan kepribadian yang mengutamakan kebebasan intelektual, sekaligus mempunyai sikap toleran terhadap berbagai pandangan dan kepercayaan yang berbeda serta terbebas dari dogmatisme dan fanatisme, selengkapnya baca: Rekonstruksi Metodologi Studi Islam dalam Masyarakat Multikultural dan Multireligius, Tulisan M. Amin Abdullah, (Yogya: IAIN Sunan Kalijaga, 2000), h. 11-13. Dapat juga dibaca dalam, Studi Agama Normativitas dan Historisitas, Amin Abdullah, (Yogya: Pustaka Pelajar, 1999), Cet. Ke-2, h. 52.

${ }^{24}$ Khaled Abou El-Fadl, Selamatkan Islam dari Muslim Puritan, h. 260. 
karena persinggungan satu sama lain akan secara berangsur-angsur menemukan kebenaran dalam suatu "titik pertemuan". Dalam istilah al-Qur'an "kalimah sa wa” seperti dalam surat Ali Imron 64:

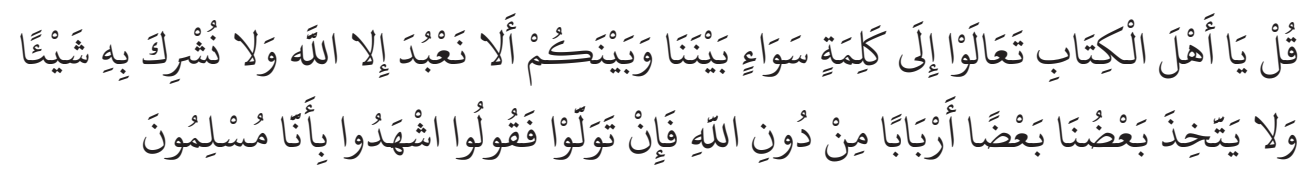

Artinya: "Katakanlah: "Hai Ahli Kitab, marilah (berpegang) kepada suatu kalimat (ketetapan) yang tidak ada perselisihan antara kami dan kamu, bahwa tidak kita sembah kecuali Allah dan tidak kita persekutukan Dia dengan sesuatu pun dan tidak (pula) sebagian kita menjadikan sebagian yang lain sebagai tuhan selain Allah. Jika mereka berpaling maka katakanlah kepada mereka: "Saksikanlah, bahwa kami adalah orang-orang yang berserah diri (kepada Allah)".

Karena terdapat paralelisme bahkan identifikasi antara sikap "tidak menyembah selain Tuhan dengan "al Islam" sebagaimana pengertian generiknya (yakni sebelum "Islam" menjadi "proper name" agama bagi Nabi Muhammad), maka titik temu agama-agama semuanya tidak lain adalah "al Islam" dalam makna generiknya itu. Maka sekali lagi sikap berserah diri setulusnya kepada Allah tanpa sedikit pun mengasosiasikan atribut ketuhanan terhadap apa dan siapa juga selain dari-Nya sendiri: adalah satu-satunya sikap keagamaan yang benar dan sikap selain itu dengan sendirinya tertolak. ${ }^{25}$

Pemaknaan yang serupa terhadap kata "Islam" (Ali Imron: 85) juga dilakukan oleh Sachedina. Menurut dia "that the word Islam refers to the act of surrender rather than to the name of a specific religion in this verse is corroborated by forms of the verb aslama ("the submitted, surrendered") in the literal sense rather than in the technical sense as derivatives of name Islam". Bahwa kata Islam lebih menunjuk kepada perilaku berserah diri dari pada menunjuk norma dari agama tertentu. Hal ini dikuatkan oleh fakta bahwa dua ayat sebelumnya yaitu surat Ali Imron ayat 83 dan 84 menggunakan bentuk kata "aslama" dalam pengertian yang literal dari pada pengertian teknikal sebagai derivasi dari nama Islam. ${ }^{26}$

${ }^{25}$ Nurcholis Majid, Islam Doktrin dan Peradaban, (Jakarta: Paramadina, 2005) dan Civil Society, Mansoor Al Jamri (ed) dan Mahnun Husen (Penerjemah), (Yogya: Tiara Wacana , 2007), h. 55 .

${ }^{26}$ Abdul Aziz Sachedina, The Islamic Roots of Democratic Pluralism, (New York: Oxford University Press, 2001), h. 39. 
Millatī, Journal of Islamic Studies and Humanities, Vol. 2, No. 2, Des. 2017: 145-168

Sementara itu Tariq Ramadhan menyebutkan bahwa “... in the al-Qur'an the word Islam has two meanings. The first is universal and generic: all the elements, as we have said in part 1. Are "in submission" to God because they respect the order of creation; in the same sense, all the revelations and prophets came with a message of the oneness of God and the need to "submit oneself" to Him. Thus Abraham, well the revelation of the Quran, is commanded by God". And when his lord said to him "submit (aslim) 'he replied, I submit (aslamtu) to the lord of the world. The words aslim and aslamtu come from Islam in the sense of recognition of the one God and acceptance of the obedience due to Him. The second meaning of the word Islam is the religion whose text is the Quran and whose prophet is Muhammad. Literalist scholars have interpreted these verses giving the word the restricted meaning of the second definition, while the generic definition makes better sense of the Islamic message as a whole, which, a part from being the final revelation identifies naturall religion, one and unique throughout history, as the recognition of the existence of creater and conformance to His message. This is also confirmed by the verse (Q: $1: 62){ }^{27}$

Secara ringkas dapat dikatakan bahwa menurut Tariq Ramadhan kata "Islam" memiliki dua makna. Yang pertama, berarti penyerahan diri kepada Allah, sebagaimana tersebut dalam surat al Baqarah ayat 131:

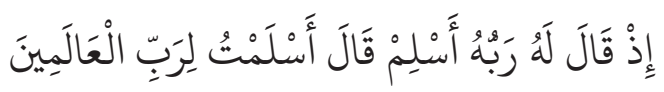

Artinya: "Ketika Tuhannya berfirman kepadanya: "Tunduk patuhlah!" Ibrahim menjawab: "Aku tunduk patuh kepada Tuhan semesta alam".

Makna yang kedua, dari kata "Islam" adalah agama yang dibawa oleh Nabi Muhammad sebagaimana dipahami oleh orang-orang literalis. Definisi secara generik menurut Tariq merupakan makna yang lebih baik terkait misi Islam sebagai satu keseluruhan. Pendapat ini dikuatkan dengan surat al Baqarah ayat 62 :

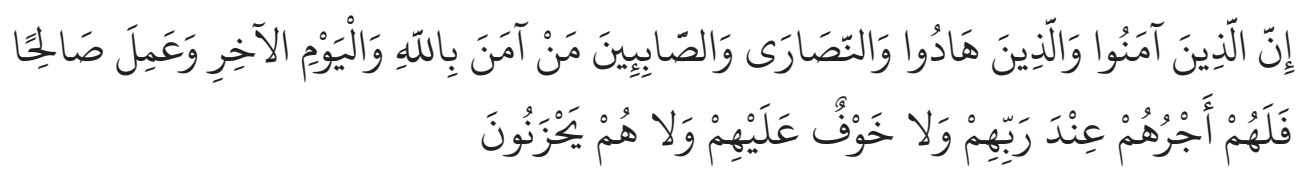

Artinya: "Sesungguhnya orang-orang mukmin, orang-orang Yahudi, orang-orang Nasrani dan orang-orang Shabiin, siapa saja di antara mereka yang benar-benar beriman kepada

${ }^{27}$ Tariq Ramadhan, Western Muslim and The Future of Islam, (New York: Oxford University Press, 2004), h. 206. 
Allah, hari kemudian dan beramal saleh, mereka akan menerima pahala dari Tuhan mereka, tidak ada kekhawatiran terhadap mereka, dan tidak (pula) mereka bersedih hati".

Ajaran Islam dalam pengertian generik adalah inti dan saripati semua agama para Nabi dan Rasul. Sekalipun secara sosiologis dan formal kemasyarakatan seseorang adalah beragama Islam atau muslim, namun jika tidak ada padanya ketulusan sikap al-Islam itu (sikap penuh pasrah dan berserah diri kepada Allah) maka ia juga termasuk kategori keagamaan yang tidak sejati dan tertolak. ${ }^{28}$

Al-Qur'an memberikan jawaban yang sangat tegas dengan pernyataan mereka yang bersifat eksklusif dan pernyataan mereka bahwa hanya mereka sajalah yang memperoleh petunjuk dari Allah, sebagaimana klaim orang Yahudi dan Nasrani yang termuat dalam surat al Baqarah ayat 113 dan 111:

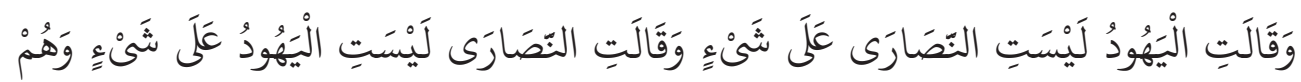

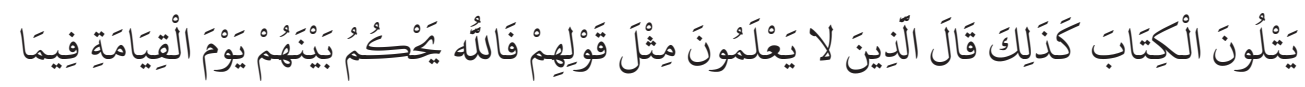

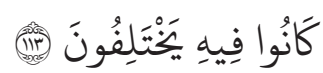

Artinya: "Dan orang-orang Yahudi berkata: "Orang-orang Nasrani itu tidak mempunyai suatu pegangan", dan orang-orang Nasrani berkata: "Orang-orang Yahudi tidak mempunyai sesuatu pegangan," padahal mereka (sama-sama) membaca Al Kitab. Demikian pula orang-orang yang tidak mengetahui, mengatakan seperti ucapan mereka itu. Maka Allah akan mengadili di antara mereka pada hari kiamat, tentang apa-apa yang mereka berselisih padanya".

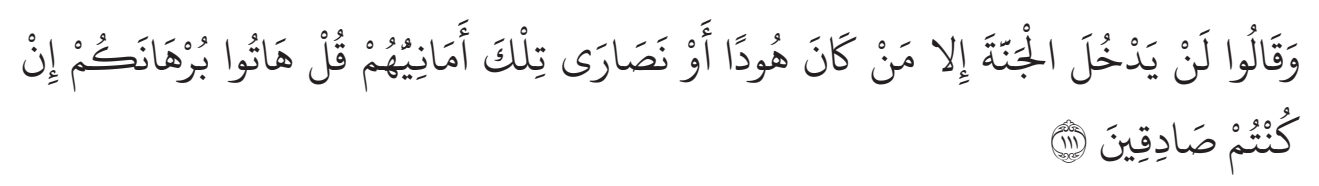

Artinya: "Dan mereka (Yahudi dan Nasrani) berkata: "Sekali-kali tidak akan masuk surga kecuali orang-orang (yang beragama) Yahudi atau Nasrani". Demikian itu (hanya) angan-angan mereka yang kosong belaka. Katakanlah: "Tunjukkanlah bukti kebenaranmu jika kamu adalah orang yang benar".

${ }^{28}$ Nurcholis Majid, Islam Doktrin dan Peradaban, h. 182.

Mohammad Arkum bahwa sebenarnya agama alam semesta ini ialah al Islam yaitu sikap pasrah yang total terhadap Sang Maha Pencipta. Baca Islam Kontemporer, M. Arkum, Ruslani (Penerjemah), (Yogyakarta: Pustaka Pelajar, 2001), h. 9. 
Millatī, Journal of Islamic Studies and Humanities, Vol. 2, No. 2, Des. 2017: 145-168

Menurut Fazlur Rahman, surat al Baqarah ayat 112 adalah contoh dari jawaban al-Qur'an terhadap klaim-klaim eksklusif. ${ }^{29}$

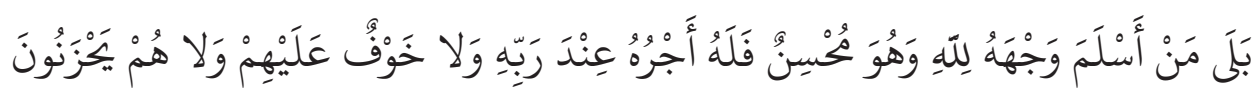

Artinya: "(Tidak demikian) bahkan barang siapa yang menyerahkan diri kepada Allah, sedang ia berbuat kebajikan, maka baginya pahala pada sisi Tuhannya dan tidak ada kekhawatiran terhadap mereka dan tidak (pula) mereka bersedih hati".

Sebaliknya, al-Qur'an secara berulang kali mengakui adanya manusiamanusia yang saleh dalam kaum Yahudi, Kristen, dan Shabiin, seperti pengakuannya terhadap adanya manusia-manusia yang beriman di dalam Islam. al-Qur'an mengakui bahwa keyakinan dan hukum agama yang plural bisa absah. al-Qur'an menyatakan:

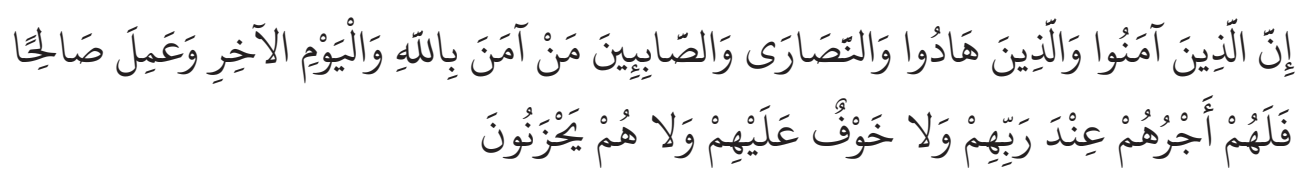

Artinya: "Sesungguhnya orang-orang mukmin, orang-orang Yahudi, orang-orang Nasrani dan orang-orang Shabiin, siapa saja di antara mereka yang benar-benar beriman kepada Allah, hari kemudian dan beramal saleh, mereka akan menerima pahala dari Tuhan mereka, tidak ada kekhawatiran terhadap mereka, dan tidak (pula) mereka bersedih hati".

Selain ayat tersebut, El-Fadl ${ }^{30}$ juga menyebut surat Ali Imron ayat 199:

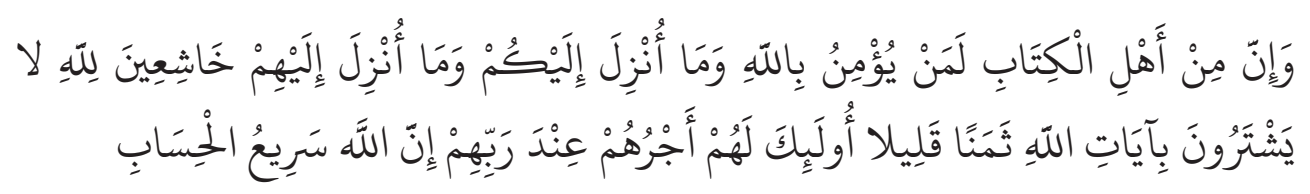

Artinya: "Dan sesungguhnya di antara ahli kitab ada orang yang beriman kepada Allah dan kepada apa yang diturunkan kepada kamu dan yang diturunkan kepada mereka sedang mereka berendah hati kepada Allah dan mereka tidak menukarkan ayatayat Allah dengan harga yang sedikit. Mereka memperoleh pahala di sisi Tuhan-nya. Sesungguhnya Allah amat cepat perhitungan-Nya".

${ }^{29}$ Fazlur Rahman, Tema Pokok al-Qur'an, (Bandung: Pustaka Pelajar, 1996), h. 238-239. Baca juga El-Fadl, Selamatkan Islam dari Muslim Puritan, h. 251-252.

${ }^{30}$ Khaled Abou El-Fadl, Selamatkan Islam dari Muslim Puritan, h. 260. 
Menurut Fazlur Rahman, mayoritas komentator-komentator muslim dengan sia-sia telah berusaha untuk tidak menerima maksud yang jelas sekali dinyatakan oleh kedua ayat tersebut: bahwa orang-orang dari kaum yang manapun juga - yang mempercayai Allah dari hari kiamat serta melakukan amalan-amalan akan memperoleh keselamatan. Komentator-komentator tersebut mengatakan bahwa yang dimaksud dengan orang-orang Yahudi, Kristen, dan Shabi'in di dalam ayat-ayat tersebut adalah orang-orang Yahudi, Kristen, dan Shabi' in yang telah masuk Islam. Penafsiran ini jelas sekali salah karena seperti yang terlihat di dalam ayat-ayat tersebut, orang-orang muslim adalah yang pertama di antara keempat kelompok "orang-orang yang percaya kepada ..." selanjutnya komentatorkomentator tersebut mengatakan bahwa mungkin pula yang dimaksudkan dengan orang-orang Yahudi, Kristen, dan Shabi'in itu adalah orang-orang Yahudi, Kristen, Shabi'in yang saleh sebelum kedatangan Nabi Muhammad inilah penafsiran yang lebih salah. ${ }^{31}$

Orang-orang moderat melihat sebuah poin kecil namun penting dalam diskursus al-Qur'an ini, yakni orang-orang Islam yang beriman dan melakukan kebajikan akan memperoleh keselamatan dan menerima pahala besar di hari akhir, akan tetapi al-Qur'an cukup konsisten mengenai tidak bolehnya berspekulasi tentang siapa yang berhak menjadi penerima rahmat Tuhan. Al-Qur'an membiarkan terbuka kemungkinan bahwa non muslim menerima anugrah Tuhan juga. Orang-orang moderat percaya bahwa hal ini dimaksudkan untuk menunjukkan sikap dasar yang selayaknya dijadikan pegangan oleh umat Islam dalam berinteraksi dengan orang lain. ${ }^{32}$

Orang-orang moderat menegaskan bahwa sementara umat manusia selayaknya bekerja sama dalam rangka mencari kebaikan seperti tersebut dalam surat al Maidah ayat 48:

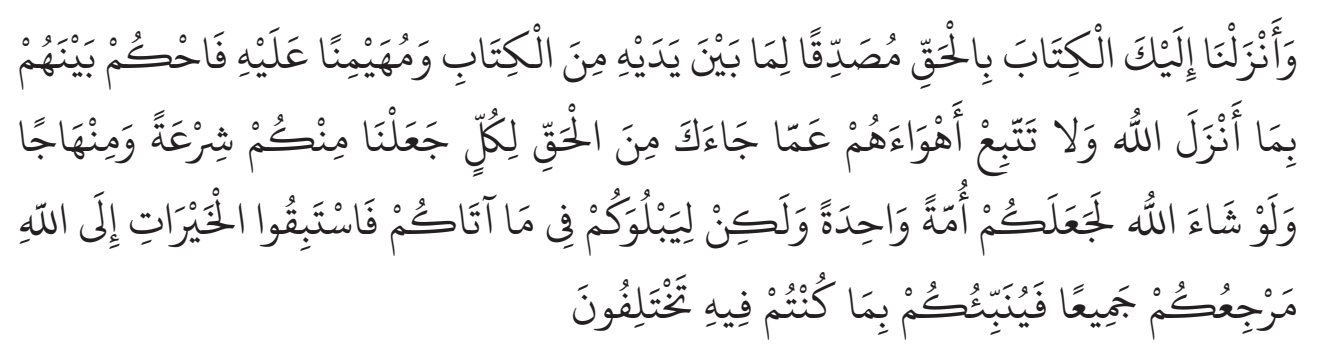

${ }^{31}$ Fazlur Rahman, Tema Pokok al-Qur'an, h. 239.

${ }^{32}$ Khaled Abou El-Fadl, Selamatkan Islam dari Muslim Puritan, h. 261. 
Millatī, Journal of Islamic Studies and Humanities, Vol. 2, No. 2, Des. 2017: 145-168

Artinya: "Dan Kami telah turunkan kepadamu Al Qur'an dengan membawa kebenaran, membenarkan apa yang sebelumnya, yaitu kitab-kitab (yang diturunkan sebelumnya) dan batu ujian terhadap kitab-kitab yang lain itu; maka putuskanlah perkara mereka menurut apa yang Allah turunkan dan janganlah kamu mengikuti hawa nafsu mereka dengan meninggalkan kebenaran yang telah datang kepadamu. Untuk tiap-tiap umat di antara kamu, Kami berikan aturan dan jalan yang terang. Sekiranya Allah menghendaki, niscaya kamu dijadikan-Nya satu umat (saja), tetapi Allah hendak menguji kamu terhadap pemberian-Nya kepadamu, maka berlomba-lombalah berbuat kebajikan. Hanya kepada Allah-lah kembali kamu semuanya, lalu diberitahukan-Nya kepadamu apa yang telah kamu perselisihkan itu".

Ayat tersebut menurut El-Fadl dengan jelas menyodorkan keragaman dan pluralisme hukum. Pada kenyataannya sudah menjadi bagian dari tujuan Tuhanlah bahwa manusia tetap berbeda dalam sejumlah hal penting dan signifikan. Beranjak dari perspektif tersebut, setiap universalisme yang hendak menafikan semua perbedaan dan menimpakan sebuah hukum yang bersifat mau menyatukan dan tunggal atas manusia akan mendapat tantangan dari teks al-Qur'an. ${ }^{33}$

Menurut Fazlur Rahman ${ }^{34}$ manfaat positif dari keanekaragaman agamaagama dan kaum-kaum ini adalah agar mereka saling berlomba dalam kebajikan sebagaimana disebutkan dalam al-Qur'an surat Al Baqarah ayat 148.

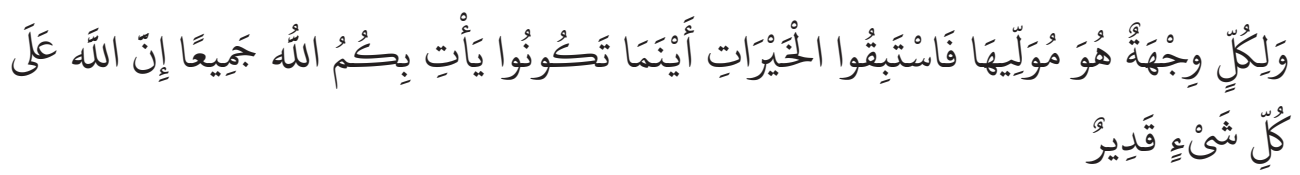

Artinya: "Dan bagi tiap-tiap umat ada kiblatnya (sendiri) yang ia menghadap kepadanya. Maka berlomba-lombalah kamu (dalam berbuat) kebaikan. Di mana saja kamu berada pasti Allah akan mengumpulkan kamu sekalian (pada hari kiamat). Sesungguhnya Allah Maha Kuasa atas segala sesuatu”.

Menanggapi sikap moderat ini, orang-orang puritan merujuk ayat-ayat al-Qur'an yang mengulas persoalan wala' (membangun aliansi dengan non muslim) untuk membuktikan bahwa Islam melarang setiap bentuk persahabatan apalagi kooperatif aktif, antara kaum muslim dan non muslim. Seperti surat al Baqarah ayat 190-194:

\footnotetext{
${ }^{33}$ Ibid., h. 254.

${ }^{34}$ Fazlur Rahman, Tema Pokok al-Qur'an, h. 240.
} 


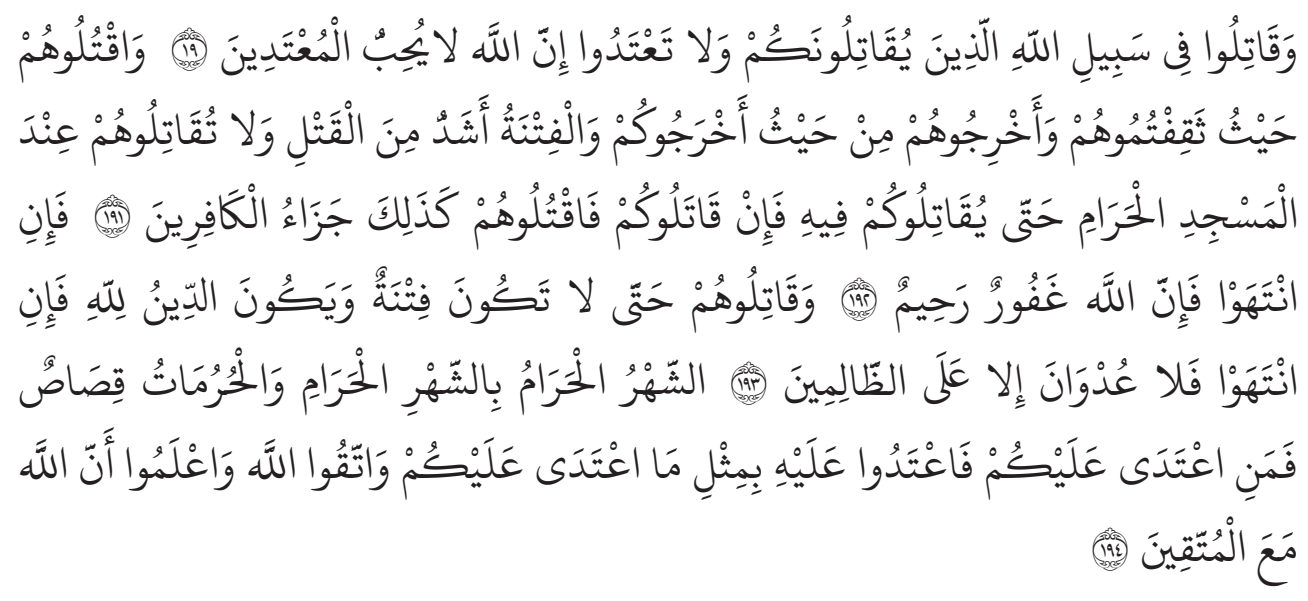

Artinya: "Dan perangilah di jalan Allah orang-orang yang memerangi kamu, (tetapi) janganlah kamu melampaui batas, karena sesungguhnya Allah tidak menyukai orangorang yang melampaui batas (190). Dan bunuhlah mereka di mana saja kamu jumpai mereka, dan usirlah mereka dari tempat mereka telah mengusir kamu (Mekah); dan fitnah itu lebih besar bahayanya dari pembunuhan, dan janganlah kamu memerangi mereka di Masjidilharam, kecuali jika mereka memerangi kamu di tempat itu. Jika mereka memerangi kamu (di tempat itu), maka bunuhlah mereka. Demikianlah balasan bagi orang-orang kafir (191). Kemudian jika mereka berhenti (dari memusuhi kamu), maka sesungguhnya Allah Maha Pengampun lagi Maha Penyayang (192). Dan perangilah mereka itu, sehingga tidak ada fitnah lagi dan (sehingga) ketaatan itu hanya semata-mata untuk Allah. Jika mereka berhenti (dari memusuhi kamu), maka tidak ada permusuhan (lagi), kecuali terhadap orang-orang yang lalim (193). Bulan haram dengan bulan haram, dan pada sesuatu yang patut dihormati, berlaku hukum kisas. Oleh sebab itu barang siapa yang menyerang kamu, maka seranglah ia, seimbang dengan serangannya terhadapmu. Bertakwalah kepada Allah dan ketahuilah, bahwa Allah beserta orang-orang yang bertakwa (194)".

Menurut El-Fadl, ayat-ayat non aliansi semuanya diwahyukan ketika terjadi perseteruan yang sengit dan tiada henti di antara kaum muslim, dan alQur'an cukup beralasan bila memerintahkan umat Islam untuk tidak membantu pihak musuh, karena dapat menimbulkan kerugian di pihak Islam. Namun ini tidak berarti bahwa al-Qur'an memerintahkan agar umat Islam terlebih dahulu menciptakan situasi terpolarisasi dan syarat konflik..$^{35}$ Lebih jauh ElFadl menegaskan bahwa orang-orang moderat percaya jika teks al-Qur'an dibaca dari perspektif kontekstual, menjadi jelas bahwa ayat-ayat yang berbeda adalah

${ }^{35}$ Khaled Abou El-Fadl, Selamatkan Islam dari Muslim Puritan, h. 256. 
Millatī, Journal of Islamic Studies and Humanities, Vol. 2, No. 2, Des. 2017: 145-168

bagian dari diskursus kompleks dan berlapis-lapis dalam merespon beragam situasi historis. ${ }^{36}$

Sebaliknya ayat-ayat yang berbicara tentang toleransi dan kerja sama oleh orang puritan dinyatakan dihapus. Artinya ayat-ayat yang berbicara tentang toleransi dengan orang non muslim batal dan tidak berlaku lagi, Tuhanlah yang memutuskan untuk menghapuskan semua ayat-ayat tersebut. Hanya pada saat umat Islam dalam keadaan lemah Tuhan mendorong untuk toleran kepada non muslim. Tetapi ketika umat Islam kuat, Tuhan memerintahkan umat Islam untuk menghancurkan semua non muslim atau minimal membenci mereka. ${ }^{37}$ Contoh ayat yang dimaksud adalah surat al Mumtahanah ayat 8-9:

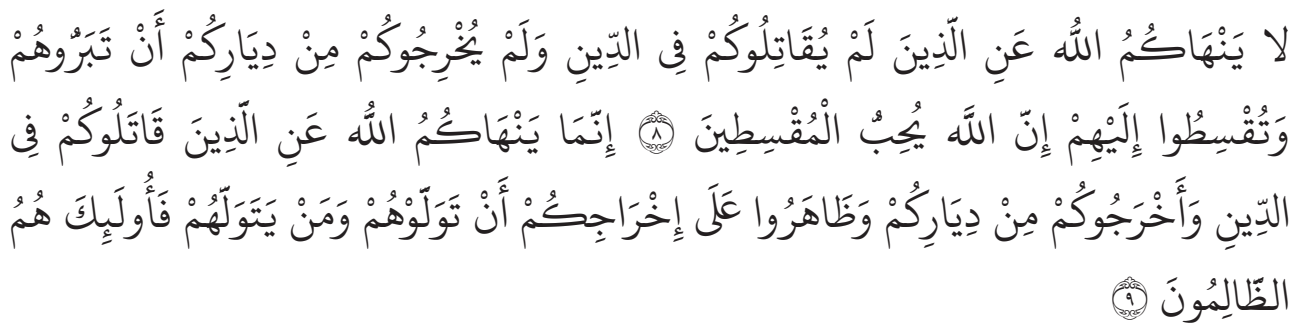

Artinya: "Allah tiada melarang kamu untuk berbuat baik dan berlaku adil terhadap orang-orang yang tiada memerangimu karena agama dan tidak (pula) mengusir kamu dari negerimu. Sesungguhnya Allah menyukai orang-orang yang berlaku adil (8). Sesungguhnya Allah hanya melarang kamu menjadikan sebagai kawanmu orang-orang yang memerangi kamu karena agama dan mengusir kamu dari negerimu dan membantu (orang lain) untuk mengusirmu. Dan barang siapa menjadikan mereka sebagai kawan, maka mereka itulah orang-orang yang dzalim (9)".

Orang-orang moderat menilai orang-orang puritan telah menggunakan logika oportunistik yang tidak layak disandangkan pada Tuhan. Orang-orang puritan biasanya menyatakan bahwa setiap bagian dari al-Qur'an yang tidak sejalan dengan pandangan mereka sebagai terhapus (dinaskh), bukan oleh manusia yang menafsirkan teks melainkan oleh Tuhan. Dalam hal ini orangorang puritan mengklaim bahwa apa yang mereka sebut ayat-ayat jihad telah membatalkan semua ayat al-Qur'an tentang toleransi dan pengampunan. ${ }^{38}$ Yang dimaksud dengan ayat jihad tersebut misalnya terdapat dalam surat An Nisa' ayat 89 .

\footnotetext{
${ }^{36}$ Ibid., h. 255.

${ }^{37}$ Ibid., h. 361.

${ }^{38}$ Ibid., h. 262.
} 


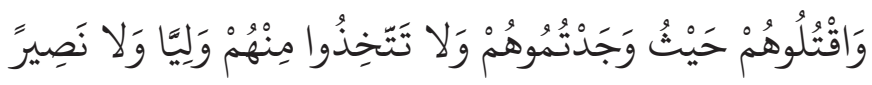

Artinya: "... dan bunuhlah mereka di mana saja kamu menemuinya, dan janganlah kamu ambil seorang pun di antara mereka pelindung, dan jangan (pula) menjadi penolong".

Terkait dengan teori naskh (abrogation) ini Husyein Atay menjelaskan pendapatnya:

"The entire text of the Quran to be valid for all times. The abrogating and abrogated verses (e, $g$, those urging war and those proposing co-existence in relation to non-muslims) continue to part of life. Hence there is nothing redundant in the Quran By rejecting abrogation, all Quran verses, including those that differ from each other, are seen to present a rich resource for solving a multitude of problems. If the theory of abrogation is accepted, the scope of the Quranic text will be narrowed. ${ }^{39}$

Selanjutnya tentang penerimaan yang tanpa syarat oleh orang-orang puritan terhadap status dzimmah bagi kaum non Islam yang hidup di wilayah muslim, mayoritas muslim moderat menolak sistem dzimmah sebagai sesuatu yang ahistoris, dalam pengertian bahwa sistem tersebut tidaklah pas untuk negara-bangsa dan demokrasi.... kondisi modernitas menuntut dihapusnya sistem itu, terutama karena jika diberlakukan di era kontemporer, sistem itu akan melecehkan tujuan keadilan dan harga diri. Apa yang membenarkan sistem pajak di abad pertengahan adalah adanya pertukaran atau timbal balik. Namun di era modern, penerapan sistem pajak unilateral oleh umat Islam akan mengakibatkan penghinaan dan keterasingan yang secara serius akan menghalangi kerja sama kooperatif yang ditujukan untuk meningkatkan kebaikan dan keadilan di dunia. ${ }^{40}$ Di samping itu, menarik untuk disimak kalimat an-naim "bahwa semua tradisi budaya keagamaan menganut prinsip apa yang disebut sebagai the golden role "yakni sebuah prinsip yang mengatakan siapapun memperlakukan orang lain seperti dia mengharapkan orang lain memperlakukan dirinya. ${ }^{41}$

${ }^{39}$ Suhataji Farouki (ed), Modern Muslim Intelectuals and The Quran, (New York: Oxford University Press, 2004), h. 248.

${ }^{40}$ Khaled Abou El-Fadl, Selamatkan Islam dari Muslim Puritan, h. 257.

${ }^{41}$ Abdullah Ahmed An-Naim, Toward in Islamic Reformation, (Syracuse University Press, 1990), h. 162-163. 
Millatī, Journal of Islamic Studies and Humanities, Vol. 2, No. 2, Des. 2017: 145-168

\section{Penutup}

Sebagaimana telah ditulis sebelumnya bahwa realitas pemikiran Islam tidak cukup dideskripsikan di dalam distingsi Moderat-Puritan, karena distingsi tersebut hanya merupakan bagian dari ragam model pemikiran orang tentang Islam.

Deretan distingsi apapun tetap menyisakan pertanyaan mengapa dari bacaan yang sama (al-Qur'an) tafsirnya berbeda? Adalah sah-sah saja, setiap orang menafsirkan tentang ayat-ayat al-Qur'an. Tetapi andai saja hal itu (tafsiran) tidak bertalian dengan implikasi sosial apapun. Sekalipun dalam hadits Nabi disebutkan bahwa "perbedaan pendapat dalam suatu umat adalah sumber rahmat. Tetapi doktrin egaliter tersebut bukan tanpa tantangan”.

"Sejarah peradaban manusia telah menyajikan kisah-kisah tragis bagaimana mereka menyatakan diri saleh seringkali membuktikan kesalehan itu dengan tindakan yang membuat orang lain menderita. Atas nama Tuhannya sendiri atau suatu etnis, seseorang seolah bisa dan boleh menindas sesama. Maka muncullah gagasan tentang penafsiran baru kesalehan keagamaan". ${ }^{42}$

Dalam tilikan psikologi agama korelasi antara intensitas religiousity dengan sikap prejudice pernah diteliti oleh GW Allport. Studi ini menghasilkan kesimpulan bahwa sikap-sikap prejudice dan tidak toleran lebih dikarenakan orientasi keagamaan seseorang dan bukan karena ajaran agama. Dia membuat model tipologi, ekstrinsik, dan intrinsik berdasarkan orientasi keagamaan seseorang. "The extrinsically motivated person uses his religion, whereas the intinsically motivated lives his religion" ${ }^{43}$ Dalam buku yang lain Allport menyatakan bahwa penelitian terakhir memperlihatkan fakta, di antara orang-orang dengan sentimen keagamaan yang sangat kuat seringkali ditandai dengan sikap prejudice. Analisis terhadap fakta ini adalah karena sentimen keagamaan mereka bersifat institusional, exclusionis, dan sangat terkait dengan kecenderungan self-centered values. Pada orang-orang dengan sentimen keagamaan yang sangat differentiated kecenderungan prejudice seperti itu hampir tidak pernah ditemukan. ${ }^{44}$ Dalam konteks ini, El-Fadl menyerukan pentingnya pemahaman Islam, karena hasil

${ }^{42}$ Elga Sarapung (ed), Th. Pluralisme, Konflik, dan Pendidikan Agama di Indonesia, (Yogya, Pustaka Pelajar, 2005), h. xvii-xviii.

${ }^{43}$ Newton Malony (ed), Current Perspectives in The Psychology of Religion, (USA: William Eerdmans Publishing Company, 1997), h. 141.

${ }^{44}$ GW. Allport, The Individual and His Religion, (New York: The Macmillan Company, 1971), h. 67. 
dari pemahaman ini akan menentukan orientasi seseorang terhadap agamanya apakah toleran atau fanatik.

Pada akhirnya, tafsir apapun akan selalu berpusat pada dua kecenderungan, pertama, tafsir yang mempertahankan mati-matian pentingnya dominasi "ruh teks" sekalipun untuk itu bahkan dilakukan intervensi, apatisasi, dan status quo. Kedua, tafsir yang lebih menonjolkan perkawinan entitas riil manusia dengan 'ruh teks', sekalipun di dalamnya terkesan terjadi distorsi, gradasi, dan reduksi terhadap 'ruh transenden' itu, ${ }^{45}$ kedua model tafsir tersebut setidaknya telah mewarnai tafsir puritan dan moderat tentang pluralitas agama.

Ada yang perlu digaris bawahi sebagaimana dikatakan oleh Syafi'i Ma'arif pemikiran manusia yang dibangun atas landasan wahyu adalah bagian dari kebudayaan, dengan demikian sifatnya adalah relatif temporer. Kebenaran wahyu yang mutlak akan menjadi relatif bila ditempatkan dalam kemasan tafsiran manusia sebagai makhluk nisbi. ${ }^{46}$ Gagasan yang sama juga dikemukakan oleh Nurcholis Majid "kita boleh melihat agama sebagai absolut karena mungkin inilah makna penganutan kepada suatu agama. Namun pemahaman kita baik pribadi maupun kelompok melalui indra, akal dan batin menyimpan kualitas manusia yang relatif". 47

The complexcity of Islamic law does not however make indetermminable. The differences of the jurists and schools of Islamic jurisprudence represent "different manifestation of the same divine will" and are considered as a diversity within unity. ${ }^{48}$

\section{DAFTAR PUSTAKA}

Allport, G.W, The Individual and His Religion, New York: The Macmillan Company, 1971.

Andito, ed, Atas Nama Agama, Bandung: Pustaka Hidayah, 1998.

An-Naim, Abdullah Ahmed, Toward in Islamic Reformation, Syracuse University Press. 1990.

Arkun, Mohammad, Islam Kontemporer, Yogya: Pustaka Pelajar, 2001.

${ }^{45}$ Nafisul Atho (ed), Hermeneutika Transenden, (Yogya: Ircisod, 2003), h. 5.

${ }^{46}$ A. Syafi'i Ma'arif, Islam Kekuatan Doktrin dan Keagamaan Umat, (Yogya: Pustaka Pelajar, 1997), h. 46.

${ }^{47}$ Andito (ed), Atas Nama Agama, (Bandung: Pustaka Pelajar, 1998), h. 61.

${ }^{48}$ Mashood A. Bederin, International Human Right and Islamic Law, (New York: Oxford University Press, 2003), h. 32 
Millatī, Journal of Islamic Studies and Humanities, Vol. 2, No. 2, Des. 2017: 145-168

Atho, Nafisul, ed, Hermeneutika Transenden, Yogya: Ircisod, 2003.

Bederin, Mashood A, International Human Right and Islamic Law, New York: Oxford University Press, 2003.

El-Fadl, Khaled Abou, Selamatkan Islam dari Muslim Puritan, Helmi Mustofa (Penerjemah), Jakarta: Serambi Ilmu Semesta, 2006.

Farouki, Suhataji, ed, Modern Muslim Intelectuals and The Quran, New York: Oxford University Press, 2004.

Haar Gerrieter, and James J. Bussutil ed, The Freedom to Do God's Will, London: Routledge, 2003.

Ma'arif, A. Syafi'I, Islam Kekuatan Doktrin dan Keagamaan Umat, Yogya: Pustaka Pelajar, 1997.

Madjid, Nurcholis, Islam Doktrin dan Peradaban, Jakarta: Paramadina, 2005.

Malony, Newton, ed, Current Perspectives in The Psychology of Religion, USA: William Eerdmans Publishing Company, 1997.

Rahman, Fazlur, Tema Pokok al-Qur'an, Bandung: Pustaka, 1996.

Ramadhan, Tariq, Western Muslims and The Future of Islam, New York: Oxford University Press, 2004.

Sachedina, Abdul Aziz, The Islamic Roots of Democratic Pluralism, New York: Oxford University Press, 2001.

Sarapung, Elga, ed, Th, Pluralisme, Konflik, dan Pendidikan Agama di Indonesia, Yogya: Pustaka Pelajar, 2005. 